\title{
SCIENTIFIC REPORTS

\section{Detection of the oil-producing microalga Botryococcus braunii in natural freshwater environments by targeting the hydrocarbon biosynthesis gene SSL-3}

\begin{abstract}
Kotaro Hirano ${ }^{1,5}$, Takuya Hara ${ }^{1,5}$, Ardianor $^{2}$, Rudy Agung Nugroho ${ }^{3}{ }^{3}$, Hendrik Segah $\mathbb{D}^{2}$, Naru Takayama ${ }^{1}$, Gumiri Sulmin², Yukio Komai ${ }^{1}$, Shigeru Okada ${ }^{4}$ \& Koji Kawamura ${ }^{*}$

The green microalga Botryococcus braunii produces hydrocarbon oils at $25-75 \%$ of its dry weight and is a promising source of biofuel feedstock. Few studies have examined this species' ecology in natural habitats, and few wild genetic resources have been collected due to difficulties caused by its low abundance in nature. This study aimed to develop a real-time PCR assay for specific detection and quantification of this alga in natural environments and to quantify spatiotemporal variations of wild $B$. braunii populations in a tropical pond. We designed PCR primers toward the hydrocarbon biosynthesis gene SSL-3 and examined amplification specificity and PCR efficiency with 70 wild strains newly isolated from various environments. The results demonstrated that this PCR assay specifically amplified $B$. braunii DNA, especially that of B-race strains, and can be widely used to detect wild $B$. braunii strains in temperate and tropical habitats. Field-testing in a tropical pond suggested a diurnal change in the abundance of $B$. braunii in surface water and found $B$. braunii not only in surface water, but also at 1-1.5 $\mathrm{m}$ deep and in bottom sediments. This method can contribute to efficient genetic resource exploitations and may also help elucidate the unknown ecology of $B$. braunii.
\end{abstract}

Microalgae are a promising renewable feedstock for biofuel production with the potential to serve as a practical alternative to petroleum-based transportation fuels ${ }^{1-3}$. Microalgal oils produced by major oleaginous microalgae, such as Chlorella spp. and diatoms, are triacylglycerols, and few species are known to produce hydrocarbons ${ }^{4}$. Hydrocarbons are preferred over triacylglycerols because of their high energy density and compatibility with existing petroleum infrastructure ${ }^{5}$. The colonial microalga Botryococcus braunii produces hydrocarbon oils at 25-75\% of its dry weight and is one of the most promising candidates for biofuel feedstock production ${ }^{1}$. The hydrocarbons are mainly stored in the extracellular space (Fig. 1), is contrast to most other oleaginous microalgae which accumulate lipids in the cytoplasm ${ }^{6}$. A catalytic hydrocracking converts the hydrocarbon oils into transport fuels such as gasoline, kerosene, and diesel ${ }^{7,8}$. Fossils of $B$. braunii have been identified in organic remains of oil shales and petroleum source rocks ${ }^{9}$, and their hydrocarbon oils are shown to be a major component of crude oils ${ }^{10,11}$, indicating the noticeable contribution of this alga to petroleum generation. Despite these remarkable characteristics of $B$. braunii, it has not yet been implemented in practical use for biofuel feedstock production. This is mainly due to its relatively slow growth rate, which makes mass cultivation in open ponds difficult to control due to competition with fast-growing microalgae ${ }^{12,13}$. The fastest growth rate in $B$. braunii has been recorded by a wild strain, Showa, with a doubling time of 1.4 days $^{14}$. Because $B$. braunii is widespread in freshwater and brackish lakes, reservoirs, or ponds from temperate to tropic environments ${ }^{13}$, it should be possible to find a novel strain that grows faster than Showa, but few studies have investigated wild genetic resources. Furthermore, there have been several reports of natural blooms of this species ${ }^{15-19}$, but the underlying mechanisms remain

${ }^{1}$ Department of Environmental Engineering, Osaka Institute of Technology, Osaka, Japan. ${ }^{2}$ University of Palangka Raya, Palangkaraya, Indonesia. ${ }^{3}$ Faculty of Mathematics and Natural Sciences, Mulawarman University, Samarinda, Indonesia. ${ }^{4}$ Graduate School of Agricultural and Life Sciences, The University of Tokyo, Tokyo, Japan. ${ }^{5}$ These authors contributed equally: Kotaro Hirano and Takuya Hara. *email: koji.kawamura@oit.ac.jp 
(a)

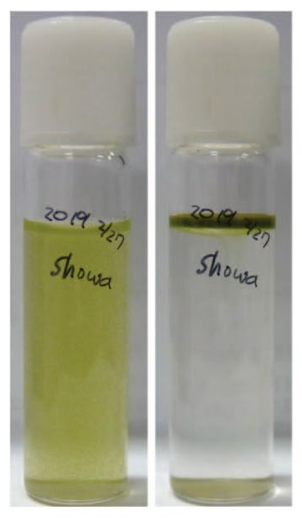

(b)

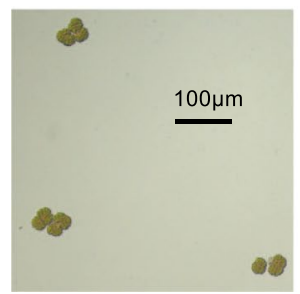

(c)

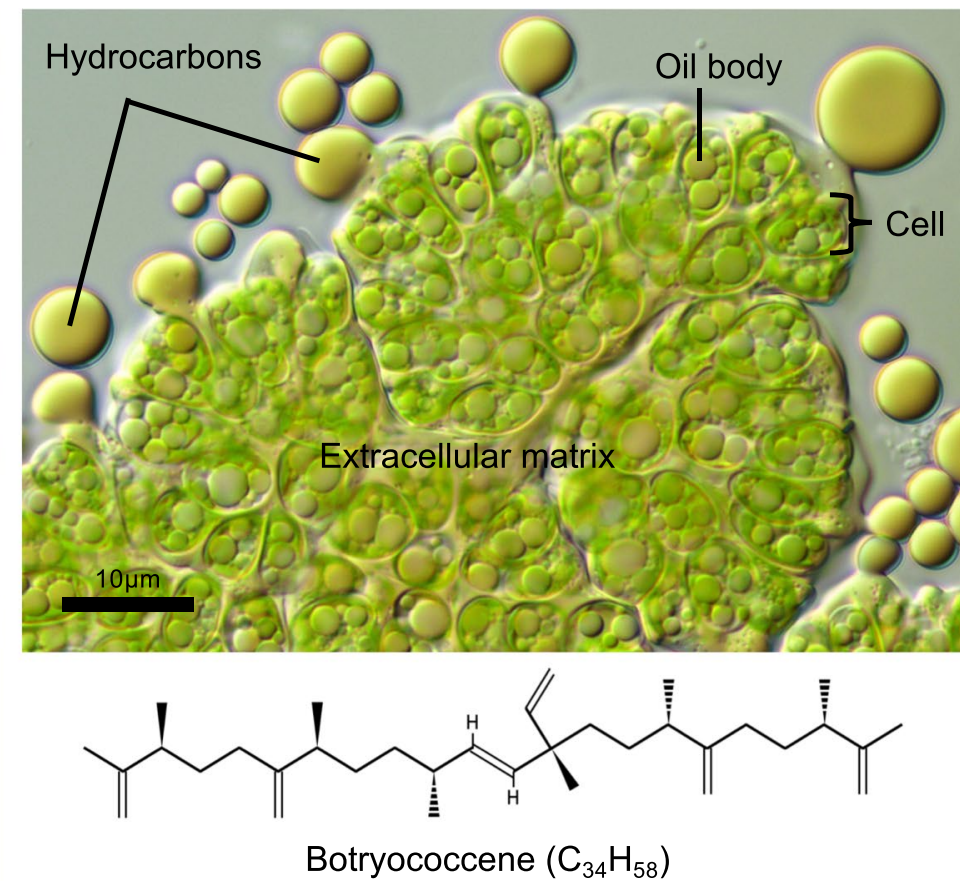

Figure 1. Characteristics of Botryococcus braunii strain Showa (race B) colonies. Botryococcus braunii is a colonial green alga. The Showa strain produces $\mathrm{C}_{\mathrm{n}} \mathrm{H}_{2 \mathrm{n}-10}(\mathrm{n}=30-34)$ hydrocarbons called botryococcenes. Botryococcenes are synthesized inside the cells of the colony and are observed as intracellular oil bodies that are secreted into the colony extracellular matrix where the majority of the hydrocarbons are stored. (a) A 10-mL glass tube culture of Showa: Left, mixed gently; Right, left undisturbed overnight, where the colonies floated upward. (b) Microscopic view of the Showa colonies. (c) The Showa colony was flattened by cover glass, and hydrocarbons exuded from extracellular matrices.

largely unknown. Elucidating the ecological and environmental factors associated with the natural blooming, including the presence of bacterial symbionts ${ }^{20}$ and density of competitors or natural enemies, would provide helpful information for the development of an open-pond B. braunii cultivation system. However, the density of B. braunii in natural environments is normally very low $\left(10-10^{2}\right.$ colonies per $\left.\mathrm{L}\right)$, which complicates quantitative investigations. Furthermore, natural life cycles of the species, including sexual reproduction and dormancy, are completely unknown. We therefore might not identify this alga in natural environments if it changes morphology, into a single-cell, gamete, or zygote form, for example. Thus, to facilitate ecological studies of $B$. braunii in natural environments, this study aimed to develop a real-time PCR assay for specific detection and quantification of wild B. braunii.

Real-time PCR is a highly sensitive technique for detecting and quantifying target DNA molecules. Target gene selection is the most important factor for the specific detection of a target organism. We focused on a hydrocarbon biosynthetic gene, squalene synthase-like protein $3(S S L-3)^{21}$ to achieve the specific detection of $B$. braunii DNA. Three chemical races of B. braunii (A, B, and L) have been identified, and their classification depends on their hydrocarbon structures. Race A produces fatty acid-derived $\mathrm{C}_{23}-\mathrm{C}_{33}$ alkadienes and triene hydrocarbons. Races $\mathrm{B}$ and $\mathrm{L}$ produce isoprenoid-derived hydrocarbons; Race B produces triterpenoid hydrocarbons, $\mathrm{C}_{30}-\mathrm{C}_{37}$ botryococcenes, and $\mathrm{C}_{31}-\mathrm{C}_{34}$ methylated squalenes, while race $\mathrm{L}$ produces the tetraterpenoid hydrocarbon $\mathrm{C}_{40}$ lycopadiene ${ }^{22}$. Recently, a new class of strain tentatively termed race $S$ was identified ${ }^{23}$, and these strains synthesize $\mathrm{C}_{18}$ epoxy- $n$-alkanes and $\mathrm{C}_{20}$ saturated $n$-alkanes. SSL-3 encodes an enzyme that catalyses the final step of $\mathrm{B}$-race hydrocarbon biosynthesis ${ }^{21}$ and is therefore expected to be useful for specific detection of $B$. braunii, especially of B-race strains. In fact, environmental studies suggested that botryococcenes are specific biomarkers of $B$. brauni $^{24,25}$. The A- and B-race strains have generally higher contents of hydrocarbons compared to L-race strains, which contain only a few percent hydrocarbons. The B-race hydrocarbons are likely a more appropriate source for biofuels than the A-race hydrocarbons owing to their branched, unsaturated structures.

The objective of this study was to assess the applicability of a real-time PCR assay of the SSL-3 gene for specific detection and quantification of B. braunii (race B) in natural environments, by examining (1) the efficiency of DNA extraction, (2) the amplification specificity of PCR, and (3) the applicability to wild strains. The chemically stable and physically resistant hydrocarbon matrix of $B$. braunii may reduce the efficiency of DNA extraction ${ }^{26}$. We therefore first assessed the efficiency of DNA extraction of our method. The PCR-based approach has a trade-off between specificity and generality. To reduce the risk of amplifying DNA from off-target organisms, it is necessary to design specific primers, but the use of highly specific primers may reduce the amplification efficiency of target organism DNA because of the possibility of genetic variation in primer-binding sequences. We therefore tested both the risk of off-target amplification and the wide applicability to genetically diverse wild strains isolated 

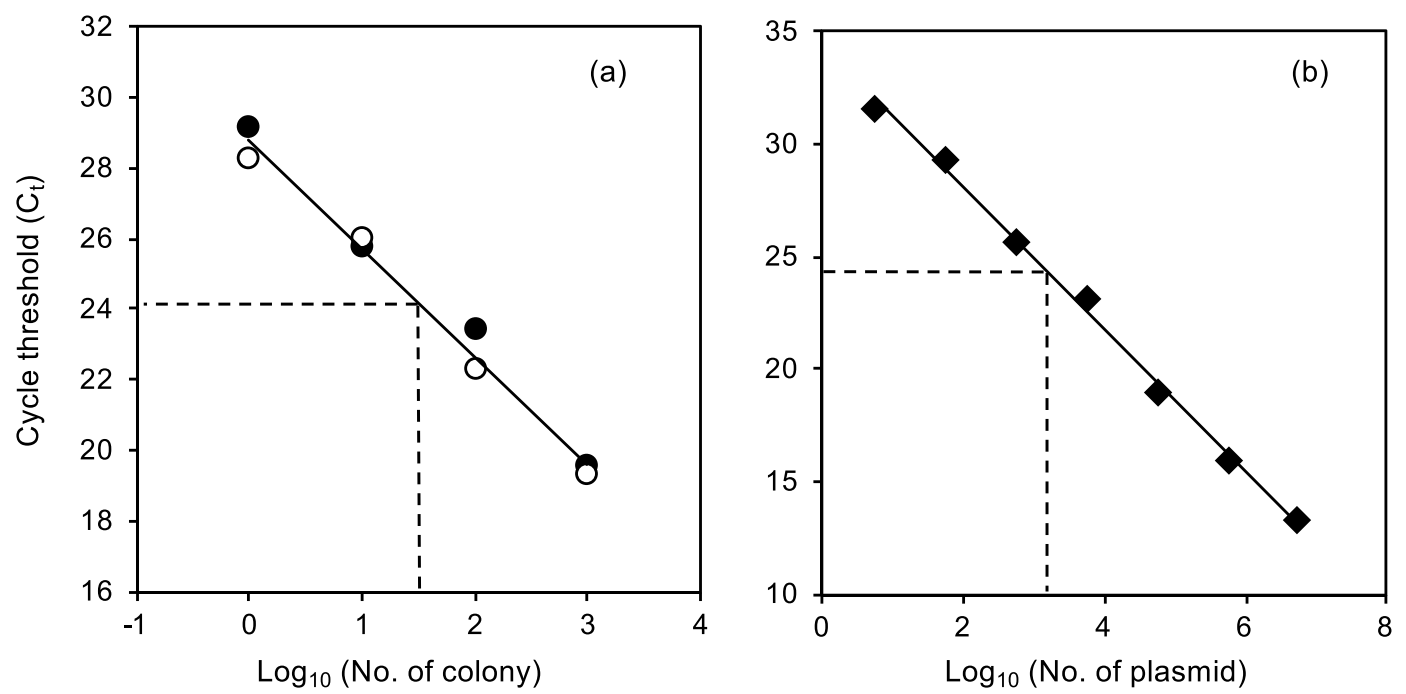

Figure 2. Standard curve of a real-time PCR assay for the SSL-3 gene in Botryococcus braunii. Standard curves were generated by correlating $C t$ values with the $\log _{10}$-transformed number of colonies and number of plasmids. (a) Standard curves generated from two series of standard samples with independent dilution and DNA extraction procedures $(\mathbf{O}, \mathrm{O}): \mathrm{y}=-3.08 \times+28.8\left(\mathrm{R}^{2}=0.987, P<0.001\right)$. (b) Standard curves generated from target sequence cloned into a plasmid $\left(\mathrm{y}=-3.16 \times+34.4, \mathrm{R}^{2}=0.997, P<0.001\right)$. Dotted lines indicate points with the same Ct value (24.2).

from temperate to tropical aquatic environments. Finally, (4) we show the results of our real-time PCR-based quantification of spatiotemporal variations of a wild B. braunii population in a tropical pond and discuss how to use our method for future ecological studies.

\section{Results and Discussion}

Standard curve generation with the Showa strain. A good relationship between Ct value and colony number was established from two series of independently prepared samples (Fig. 2a; $\mathrm{R}^{2}=0.987, P<0.001$ ), demonstrating that artificial error variances caused by DNA extraction procedures were low. The slope of the regression line ( -3.08 ; Fig. 2 a) had a $95 \%$ confidence interval from -3.43 to -2.72 and did not differ significantly from the slope obtained from a dilution series of the template plasmid (-3.16; Fig. 2b) or the theoretical slope of -3.32 . This indicates a constant DNA extraction efficiency in the range of $10^{2}-10^{5}$ colonies and an approximately ideal efficiency of PCR amplification.

A high DNA extraction efficiency from colonies was also suggested by comparing the two standard curves as well as an estimation based on genome size. Since a single Showa colony contains $55.9 \pm 7.3$ cells (Average \pm SE, $\mathrm{n}=21$ ), and the target sequence SSL-3 is a single-copy gene in the Showa genome (MVGU01001496: 9212292181, B. braunii strain Showa, PRJNA60039) ${ }^{27}$, we predict that DNA extracted from $k$ colonies would contain $55.9 k$ copies of the target sequence. This prediction can be validated by the plasmid standard curve (Fig. 2b). At an average number of colonies $\left(=10^{1.5}\right)$, the standard curve generated by extracting DNA from colonies (Fig. 2a) gives a predicted Ct value of 24.2 (with a 95\% confidence interval from 23.8 to 24.6 ). The Ct value of 24.2 corresponds to $10^{3.2}$ copies of plasmid (Fig. 2b). Therefore, the number of target sequences per DNA extracted from one colony is estimated as $52\left(=10^{3.2} / 10^{1.5}\right)$, which agreed well with the predicted value of 55.9 . Furthermore, the size of the Showa strain genome is estimated as $166.2 \mathrm{Mbp}^{28}$, which indicates that $1 \mathrm{ng}$ of DNA corresponds to 5,488 cells. We measured that total amount of DNA extracted from $10^{5}$ Showa colonies was $938 \mathrm{ng}(\mathrm{SE}=19$, $\mathrm{n}=3$ ), which corresponds to 92,000 colonies $(=938 * 5488 / 55.9)$. This again indicates a high DNA extraction efficiency (>90\%) in our standard samples.

Amplification specificity in a natural environment. The regression slopes of Ct values on Log (numbers of Showa colonies) did not differ significantly between sample series $\mathrm{P}$ (dilution by pond water) and W (dilution by distilled water; $P>0.1$, Fig. $3 \mathrm{a}$ ). This indicates that DNA extraction efficiency and PCR amplification were not affected by contamination with environmental DNA present in natural pond water. The melting curve analyses support the specific detection of the $S S L-3$ gene in the environmental DNA samples (Fig. 3b,c). The lower intercept of the regression line of series $\mathrm{P}$ compared to series W (Fig. 3a) is due to the existence of wild B. braunii strains in pond water.

A decrease in DNA extraction efficiency was found in high-density samples. Samples with $10^{6}$ Showa colonies, which corresponds to the amount of DNA template of $10^{4}$ colonies (Fig. 3a), showed higher Ct values than predicted and were not included in the regressions. This can result from decreases in DNA extraction efficiency in high-density samples and/or a decrease in PCR amplification efficiency due to inhibitory effects of the extracts. Therefore, high-density samples should be diluted prior to DNA extraction and real-time PCR. As criteria needed for dilution, we measured dry weight and optical density of the samples containing $10^{6}$ Showa colonies: Dry weight was $18 \mathrm{mg}$ for $10^{6}$ Showa colonies, and OD at $660 \mathrm{~nm}$ was 0.20 for samples with $10^{6}$ Showa colonies in 

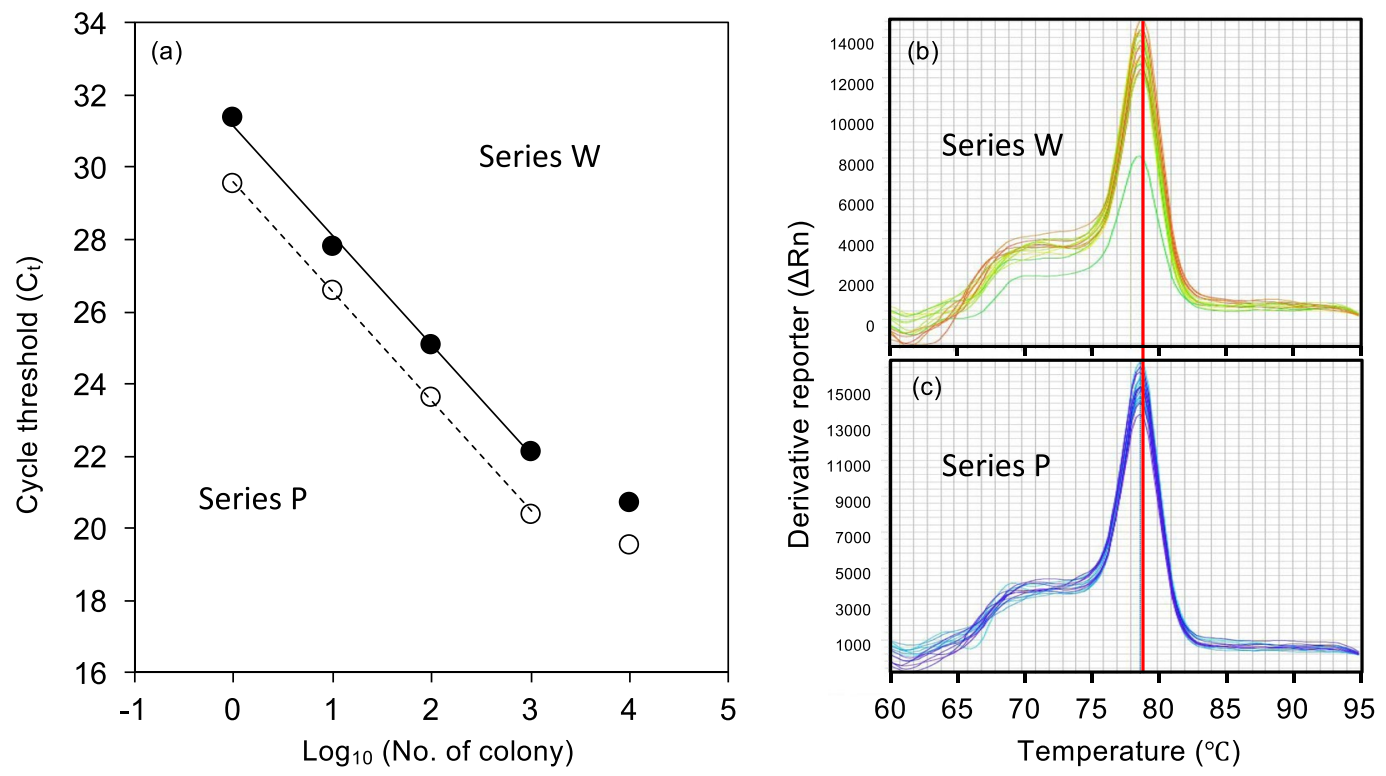

Figure 3. Amplification specificity of the real-time PCR assay for the SSL-3 gene in natural pond water. (a) Regression line between Ct values and Log (numbers of Showa colonies) obtained from Showa culture diluted with natural pond water $\left(O\right.$, Series P; Dotted line: $\left.y=-3.05 \times+29.6, R^{2}=0.999\right)$, compared with that obtained from Showa culture diluted with distilled water ( $O$, Series W; Solid line: $\left.y=-3.05 \times+31.2, \mathrm{R}^{2}=0.997\right)$. Data of $10^{6}$ Showa colonies are not included in the regressions. The biomass density of the pond water was $82.5 \mathrm{mg} \mathrm{L}^{-1}$ with an $\mathrm{OD}_{660}=0.013$. (b,c) Melting curve analyses of the real-time PCR products. Y-axis represents the derivative reporter $(\Delta \mathrm{Rn})$ while $\mathrm{x}$-axis represents the temperature $\left({ }^{\circ} \mathrm{C}\right)$. Melting curves of the real-time PCR products of (b) Series W with pure Showa culture and (c) Series P contaminated with natural pond water.

$50 \mathrm{~mL}$ of distilled water. These values can be used as indicators to determine the necessity of diluting samples prior to DNA extraction, otherwise the density of $B$. braunii in the sample will be underestimated. Kim et al. ${ }^{26}$ also reported low DNA yields of commercial kits for DNA extraction from B. braunii cells greater than $55 \mathrm{mg}$ dry weight. Such a large amount of cells will overload the filter used for collecting DNA.

Molecular phylogeny of wild strains. Figure 4 shows a molecular phylogenetic tree of $B$. braunii including 70 wild strains isolated from temperate to tropical ponds with reference sequences obtained from NCBI. The four chemical races (A, B, L, and S) were classified into four major clades as previously reported by Kawachi et al. ${ }^{23}$, indicating that they are genetically distinct. The chemical race $\mathrm{S}$ clade shows a relatively low genetic variation, indicating a recent divergence from the L clade (Fig. 4). In the B-race clade, a large sub-clade was formed with a $91 \%$ bootstrap support, which was named the $B_{2}$ clade, and includes the standard strain Showa. Other strains in the B-race clade have a large genetic variation and did not form clear sub-clade. All were classified into the $B_{1}$ clade, which has a 79\% bootstrap support.

Our tropical strains were all classified into either the B- or L-race clade, indicating that B- and L-race strains are major components of tropical B. braunii. In the B- or L-race clade, there was no clear genetic differentiation between tropical and temperate strains, indicating a frequent gene flow over a large geographic gradient. As Kawachi et al. ${ }^{23}$ discussed, birds or winds can disperse colonies of wild B. braunii. Consequently, as Janse van Vuuren \& Levanets ${ }^{19}$ reviewed recently, B. braunii is known to be a cosmopolitan phytoplankton species.

Compatibility of SSL3-targeted primers to wild strains. Table 1 summarizes the results of real-time PCR of 70 wild strains. The results were classified into 5 clades $\left(A, L, S, B_{1}, B_{2}\right)$ based on the molecular phylogenetic tree. The index of amplification efficiency of the $S S L-3$ gene $2^{-\Delta(\Delta \mathrm{Ct})}$ relative to the Showa stain was close to zero for all strains classified as A, L, and S clades. In contrast, average $2^{-\Delta(\Delta \mathrm{Ct})}$ values were 0.60 for wild strains in $\mathrm{B}_{1}$ clades and 0.89 for those in $\mathrm{B}_{2}$ clade (Fig. $5 \mathrm{a}$ ). These results demonstrate that our real-time PCR method targeting $S S L-3$ gene is highly specific to B-race strains, and off-target amplification of different strains (A, L, or S) would not occur. Niehaus et al..$^{21}$ demonstrated that $S S L-3$ was responsible for botryococcene biosynthesis in combination with another squalene synthase-like gene (SSL-1) and suggested that these SSL genes originated from the duplication of a progenitor squalene synthase gene. This gene duplication may occur in a progenitor of the race $\mathrm{B}$ clade. In fact, the biosynthesis of hydrocarbons in race A occurs through an elongation-decarboxylation route in fatty acid synthesis ${ }^{12,13,29}$. Thapa et al. ${ }^{22}$ identified a new gene coding squalene synthase-like protein, lycopaoctaene synthase (LOS), in race L of $B$. braunii, which carries out the first step in lycopadiene biosynthesis. This gene may be a good molecular marker for specific detection of race $\mathrm{L}$.

Figure $5 \mathrm{~b}$ plots individual $2^{-\Delta(\Delta \mathrm{Ct})}$ values obtained for the 70 wild strains. The variations in $2^{-\Delta(\Delta \mathrm{Ct})}$ values between strains within in the B-race clade were not associated with climate regions where the strains originate. Somewhat lower $2^{-\Delta(\Delta \mathrm{Ct})}$ values from $0.3-0.6$ were observed in strains classified into the $\mathrm{B}_{1}$ clade. As the $\mathrm{B}_{1}$ 


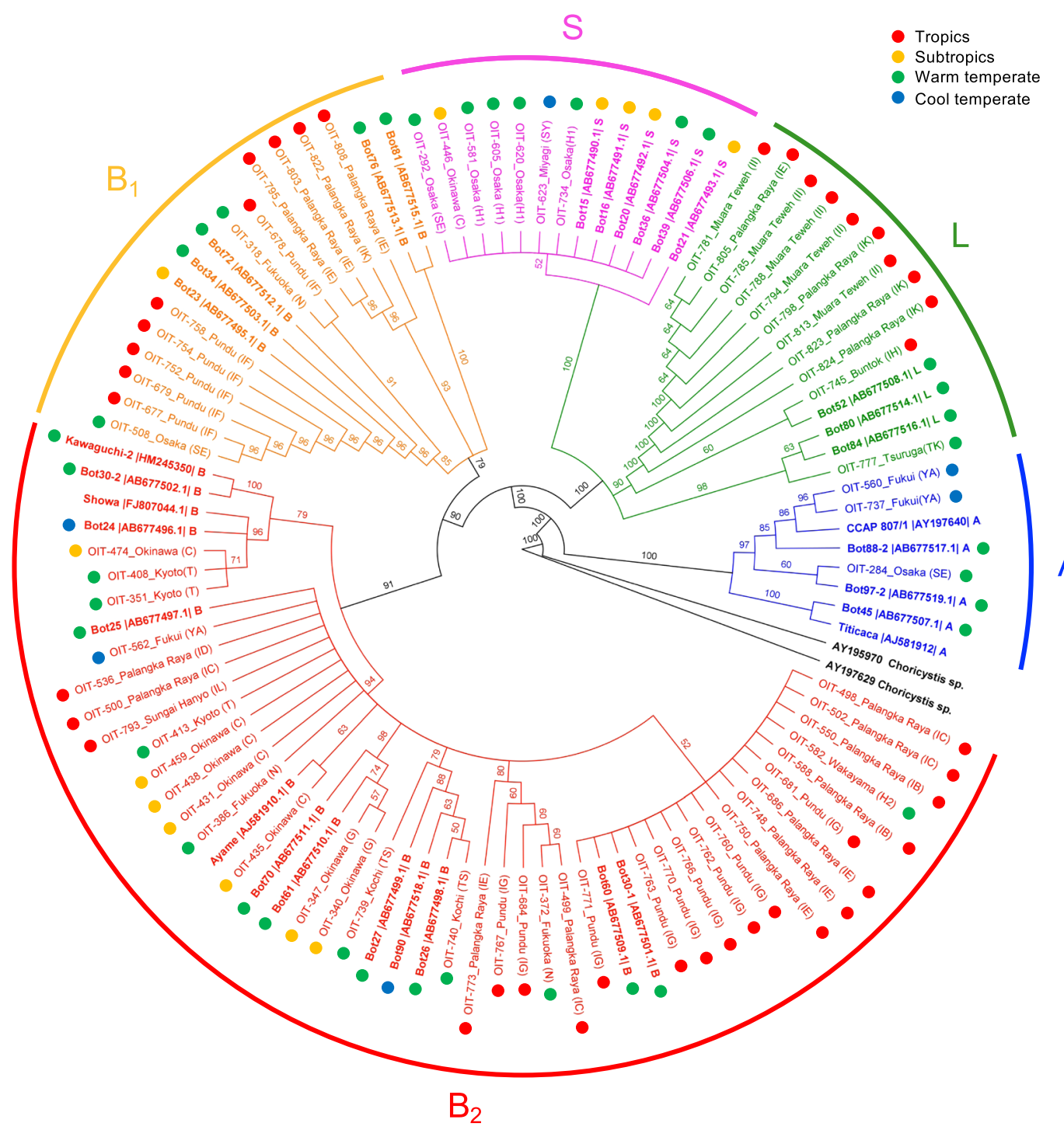

Figure 4. Molecular phylogenetic tree of Botryococcus braunii wild strains based on $18 \mathrm{~S}$ ribosomal RNA sequences. The tree is rooted on the branch between Choricystis and Botryococcus. Numbers around the internodes indicate bootstrap values in the Neighbourhood-joining analysis ( 1000 replications). Reference sequences are in bold with accession numbers and classification of chemical race $(A, B, L, S)$. The geographic location of isolation sites is also indicated.

clade is genetically diverse and distant from the standard strain Showa, some strains may have large nucleotide sequence variations at the primer binding sites, which result in decreased amplification efficiency of the target gene. Since we focused on the exon 6 of SSL-3 gene and designed our primers on a conserved site of the exon based on available sequences of only five strains (Supplementary Fig. S1), there might be more conserved sites for universal primers for B-race strains in the other regions of the gene. Sequencing of SSL-3 genes of our genetically-diverse wild strains especially in the $\mathrm{B}_{1}$ clade will help to search for such conserved sites and to provide useful information for analyzing functionally-important regions as well as for designing universal primers for detection and quantification of B-race wild strains.

Field testing in a natural habitat. Figure 6 illustrates the field test of the real-time PCR method in a tropical pond. Our real-time PCR assay successfully quantified spatio-temporal changes in wild B. braunii abundance in the pond. A 10-L water sampling method showed a diurnal change in colony density in surface water (Fig. 6d); density decreased to half at night time. The average density at night from $8 \mathrm{pm}$ to 2 am was $21.1\left(\mathrm{~L}^{-1}\right)$ and was significantly lower than that during the day from 8 am to $2 \mathrm{pm}\left(55.0, \mathrm{~L}^{-1}\right.$; ANOVA, $\left.F_{1,4}=7.7, P<0.01\right)$. In parallel, the average water temperature was lower at night $\left(28.5^{\circ} \mathrm{C}\right)$ than during the day $\left(31.5^{\circ} \mathrm{C}\right)$. This change in water temperature may induce vertical water circulation and result in the diurnal change in colony density in surface water. Since this diurnal change in colony density in surface water (Fig. 6d) is based on the data obtained in one day, repetitive experiments in different days and locations are necessary to confirm the observed pattern. 


\begin{tabular}{|c|c|c|c|c|c|c|c|c|c|}
\hline \multirow[b]{2}{*}{ Clade $^{\dagger}$} & \multirow[b]{2}{*}{$N$} & \multicolumn{2}{|l|}{$\mathrm{Ct}^{\mathrm{sSL3}}$} & \multicolumn{2}{|l|}{$\mathrm{Ct}^{18 \mathrm{~S}}$} & \multicolumn{2}{|l|}{$\Delta \mathrm{Ct}$} & \multicolumn{2}{|l|}{$2^{-\Delta(\Delta C t)}$} \\
\hline & & $\begin{array}{l}\text { Average (SE) } \\
\text { Median }\end{array}$ & $\begin{array}{l}\text { Max } \\
\text { Min }\end{array}$ & $\begin{array}{l}\text { Average (SE) } \\
\text { Median }\end{array}$ & $\begin{array}{l}\text { Max } \\
\text { Min }\end{array}$ & $\begin{array}{l}\text { Average (SE) } \\
\text { Median }\end{array}$ & $\begin{array}{l}\text { Max } \\
\text { Min }\end{array}$ & $\begin{array}{l}\text { Average (SE) } \\
\text { Median }\end{array}$ & $\begin{array}{l}\text { Max } \\
\text { Min }\end{array}$ \\
\hline A & 3 & $\begin{array}{l}31.4(0.85) \\
31.6\end{array}$ & \begin{tabular}{|l|}
32.8 \\
29.9 \\
\end{tabular} & \begin{tabular}{|l|}
$19.1(1.3)$ \\
19.9
\end{tabular} & $\begin{array}{l}20.8 \\
16.5\end{array}$ & $\begin{array}{l}12.4(1.8) \\
12.8\end{array}$ & $\begin{array}{l}15.2 \\
9.1\end{array}$ & $\begin{array}{l}0.0075(0.0065) \\
0.0015\end{array}$ & $\begin{array}{l}0.021 \\
0.00050\end{array}$ \\
\hline $\mathrm{L}$ & 11 & $\begin{array}{l}33.3(0.42) \\
33.4\end{array}$ & \begin{tabular}{|l|}
35.1 \\
30.4
\end{tabular} & $\begin{array}{l}19.7(0.12) \\
19.6\end{array}$ & $\begin{array}{l}20.2 \\
19.3\end{array}$ & $\begin{array}{l}13.6(0.40) \\
14.0\end{array}$ & $\begin{array}{l}15.5 \\
11.1\end{array}$ & $\begin{array}{l}0.0020(0.0005) \\
0.0011\end{array}$ & $\begin{array}{l}0.0056 \\
0.00040\end{array}$ \\
\hline S & 7 & $\begin{array}{l}33.3(0.73) \\
33.9\end{array}$ & $\begin{array}{l}35.7 \\
30.0\end{array}$ & $\begin{array}{l}19.5(0.53) \\
19.5\end{array}$ & $\begin{array}{l}22.4 \\
18.2\end{array}$ & $\begin{array}{l}13.8(0.89) \\
13.6\end{array}$ & $\begin{array}{l}17.6 \\
10.6\end{array}$ & $\begin{array}{l}0.0021(0.0009) \\
0.0015\end{array}$ & $\begin{array}{l}0.0073 \\
0.000095\end{array}$ \\
\hline $\mathrm{B}_{1}$ & 12 & $\begin{array}{l}25.0(0.28) \\
25.0\end{array}$ & $\begin{array}{l}26.5 \\
23.4\end{array}$ & $\begin{array}{l}20.1(0.26) \\
20.2\end{array}$ & $\begin{array}{l}21.6 \\
18.9\end{array}$ & $\begin{array}{l}4.9(0.15) \\
5.0\end{array}$ & $\begin{array}{l}5.4 \\
3.6\end{array}$ & $\begin{array}{l}0.60(0.05) \\
0.57\end{array}$ & $\begin{array}{l}0.92 \\
0.36\end{array}$ \\
\hline $\mathrm{B}_{2}$ & 37 & $\begin{array}{l}25.1(0.24) \\
24.8\end{array}$ & \begin{tabular}{|l|}
30.3 \\
23.2
\end{tabular} & $\begin{array}{l}20.8(0.25) \\
20.3\end{array}$ & $\begin{array}{l}26.5 \\
19.1\end{array}$ & $\begin{array}{l}4.4(0.06) \\
4.4\end{array}$ & $\begin{array}{l}4.9 \\
3.0\end{array}$ & $\begin{array}{l}0.89(0.03) \\
0.86\end{array}$ & $\begin{array}{l}1.38 \\
0.58\end{array}$ \\
\hline Showa ${ }^{\S}$ & & $23.5(0.25)$ & & $19.3(0.27)$ & & $4.2(0.012)$ & & 1 & \\
\hline
\end{tabular}

Table 1. Summary statistics for results of real-time PCR assay using SSL-3 and $18 S$ ribosomal gene primers with DNA templates of Botryococcus braunii strains. ${ }^{\dagger}$ Clade is classified based on the molecular phylogeny of $18 \mathrm{~S}$ ribosomal sequence. ${ }^{\S}$ Average $(\mathrm{SE})$ of $\mathrm{Ct}$ values with Showa DNA template $(N=3) . \Delta \mathrm{Ct}=\mathrm{Ct}^{\mathrm{SSL} 3}-\mathrm{Ct}^{18 \mathrm{~S}}$. $\Delta(\Delta \mathrm{Ct})=\Delta \mathrm{Ct}-\Delta \mathrm{Ct}^{\text {Showa }}$.
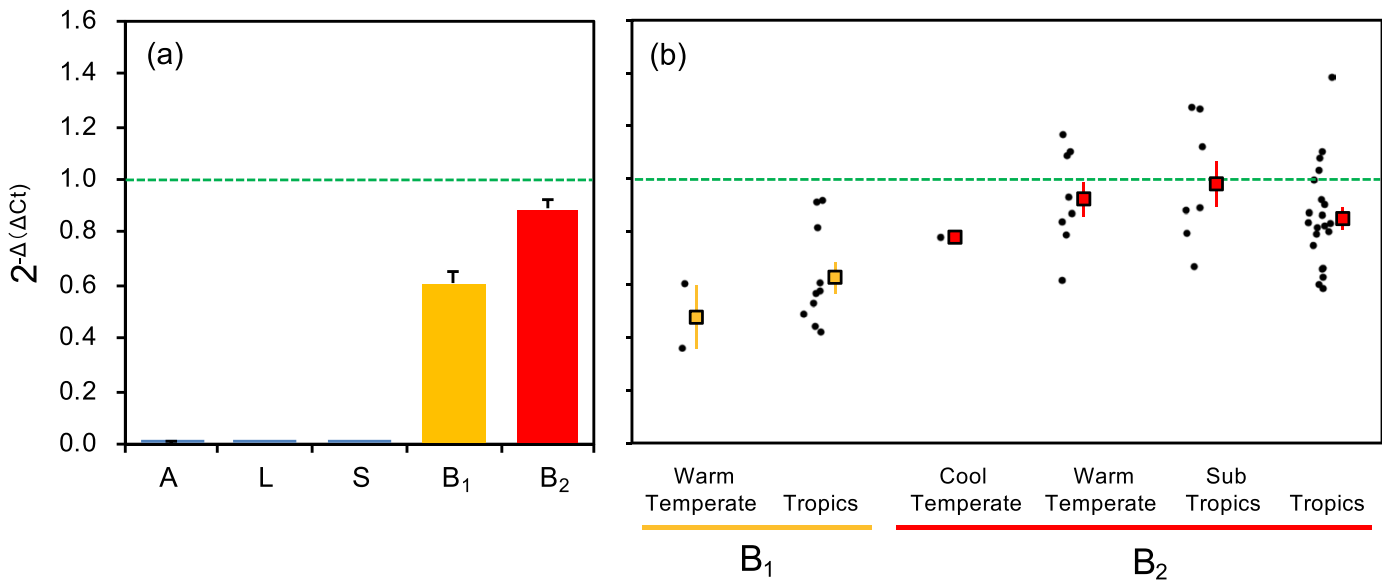

Figure 5. Index for PCR amplification efficiency of $S S L-3$. The index $2^{-\Delta(\Delta C) t}$ was calculated based on the Ct values of $S S L-3$ and $18 S$ ribosomal RNA genes, and indicates the relative amplification efficiency of the SSL-3 gene to that of standard strain Showa. (a) The $2^{-\Delta(\Delta \mathrm{Ct})}$ value was obtained for the 70 wild strains, and averaged by clades. Bars indicate standard errors. (b) The $2^{-\Delta(\Delta \mathrm{Ct})}$ values were averaged by climate regions where the wild strains were isolated. Filled circles indicate individual data of each strain, and rectangles are average values with standard error bars.

Quantification of the vertical distribution of B. braunii showed that this species inhabited all layers in the pond (Fig. 6e). Even in the bottom sediment, we detected B. braunii DNA (Fig. 6f), corresponding to 61.7 colonies per $g$ soil. In fact, $B$. braunii colonies were easily found upon microscopic observation of the soil, some of which looked alive and contained plenty of oils (Fig. 6h). In addition, we detected B. braunii DNA in the fraction of small-sized particles $<10 \mu \mathrm{m}$ (Fig. 6f), which was confirmed by microscopic observation (Fig. 6g). The observed small-sized and sedimented colonies differ from the laboratory strain Showa cultivated in a flask, which floats up to the surface layer with a colony size generally greater than $20 \mu \mathrm{m}$ (Fig. 1). Tanoi et al. ${ }^{30}$ reported that an iron-limitation treatment decreased colony sizes of $B$. braunii. The observed small and submerged colonies in the wild population may result from nutrient stresses in natural environments. The detection of $B$. braunii DNAs in the small size fraction $(<10 \mu \mathrm{m})$ as well as in bottom sediments might also result from the formation of single-celled gametes for sexual reproduction or dormant cysts in the sediments. Seasonal investigations of the abundance of wild B. braunii populations using our real-time PCR assay may help elucidate its unknown ecology and cryptic life cycles in nature.

Contributions to genetic resource exploitation and ecological studies. Our real-time PCR assay could help to efficiently exploit natural genetic resources of $B$. braunii. The real-time PCR method can quantify colony density of $B$. braunii in natural water samples in a high throughput manner (e.g., 50-100 samples per day) and help to find out high-density habitats from a large number of water samples. Subsequently, the time-consuming, microscopic isolation of wild strains can be focused on the high-density habitats. This can be an efficient strategy for wild genetic resource exploitations and might also increase a chance to isolate fast-growing strains. Because fast-growing strains are expected to increase population density, strains isolated 


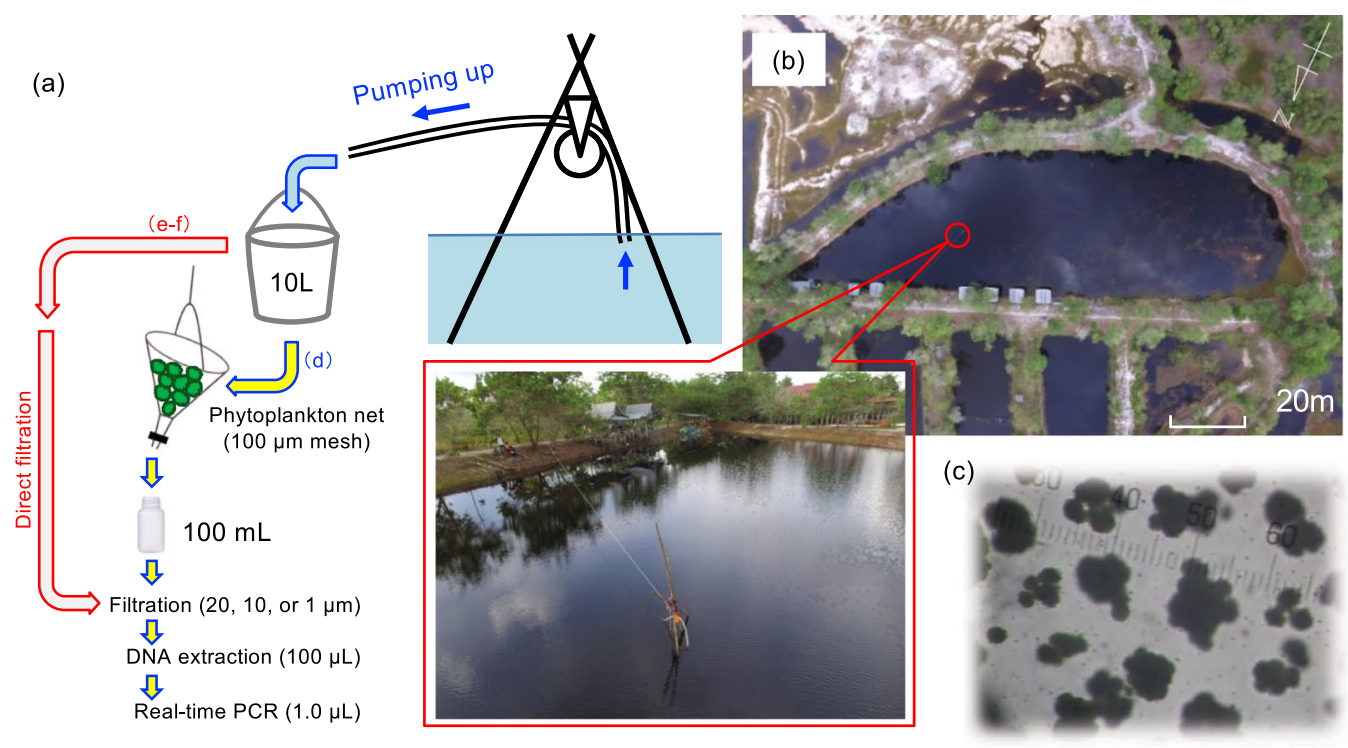

(d)

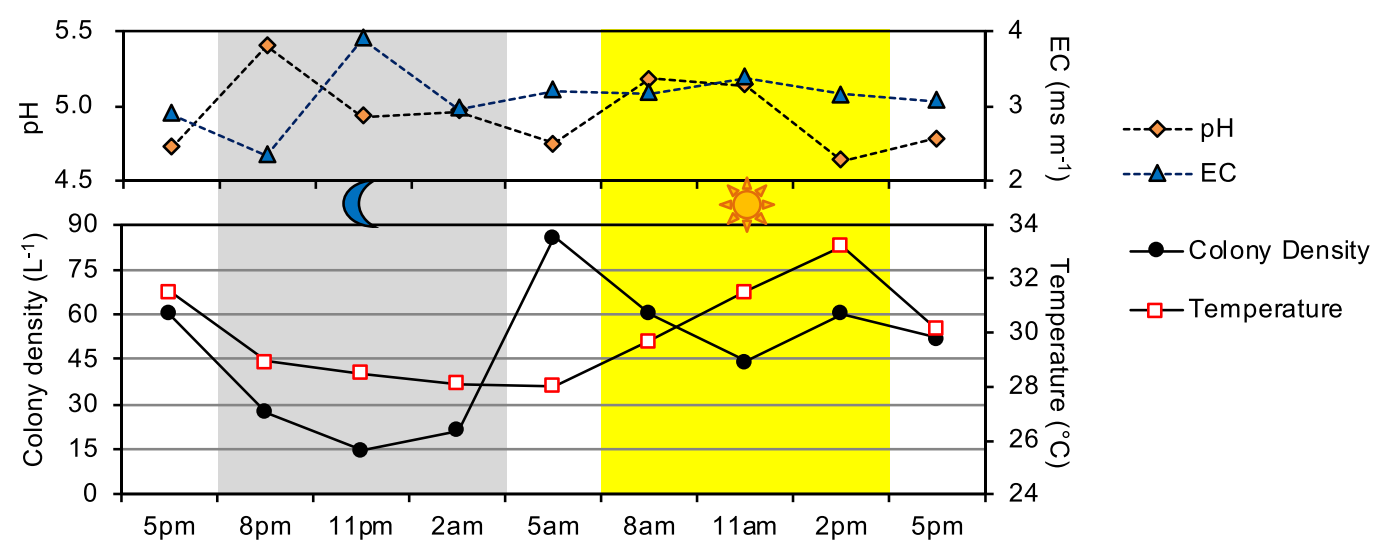

(e)

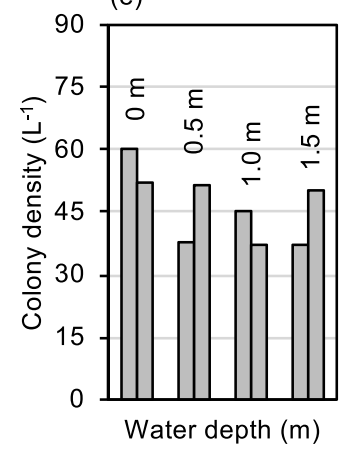

(f)

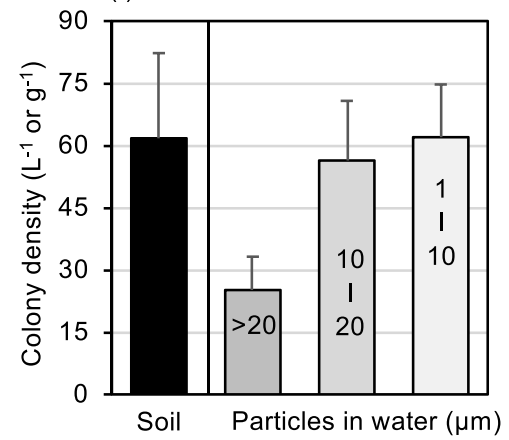

(g)

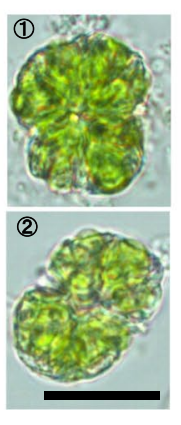

(h)

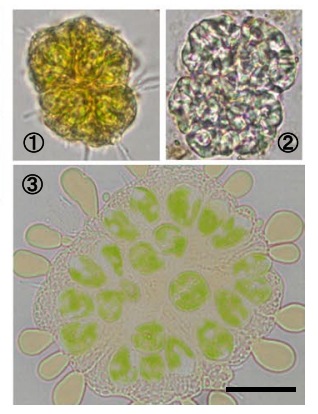

Figure 6. Field-testing of real-time PCR assay for detecting and quantifying wild B. braunii. (a) Sampling method of pond water; (b) Overview of the studied pond (IE), Palangka Raya, Indonesia; (c) Microscopic view of wild $B$. braunii colonies collected by a phytoplankton net; (d) Diurnal changes in colony density, water temperature, $\mathrm{pH}$, and electrical conductivity (EC) in the surface water of the pond; (e) Vertical distribution of $B$. braunii; (f) Colony densities in bottom sediment (soil) and different-sized particles in water; (g) Small colonies found in water samples $(\mathrm{Bar}=10 \mu \mathrm{m}) ;(\mathbf{h}) \mathrm{B}$. braunii colonies found in soil $(\mathrm{Bar}=10 \mu \mathrm{m})$.

from high-density populations are expected to be fast-growers. However, we have to note that the growth rate is not necessarily predominant factor controlling the abundance of microalgae in natural environment, since the abundance is also affected by many environmental, ecological and artificial factors (e.g., water quality, microbiome, natural enemies, and disturbance). These abiotic and biotic factors potentially affecting population density of $B$. braunii are also necessary to be investigated in addition to the real-time PCR quantification of $B$. braunii densities in natural water samples. Such efforts will elucidate underlying mechanisms of natural blooms and eventually contribute to the realization of outdoor mass cultivation of this alga for biofuel production. 


\section{Conclusions}

Based on a real-time PCR assay of a hydrocarbon biosynthetic gene, we have successfully developed a highly sensitive and specific method for detecting and quantifying the race B strain of the oil-producing microalga Botryococcus braunii in natural environments. This method can be widely applicable to both temperate and tropical freshwater environments and may be helpful to exploit genetic resources and to elucidate its unknown ecology and life cycles in nature.

\section{Methods}

Real-time PCR assay for detecting the SSL-3 gene. We designed PCR primers targeted toward the $S S L-3$ gene of $B$. braunii. Since Niehaus et al. ${ }^{21}$ suggested that the $S S L-3$ domain V is involved in functional divergence of the SSL-3 gene from other paralogous genes (SSL-1, SSL-2), we focused on Exon 6, which encodes domain V. By nucleotide sequence alignment of the SSL-3 gene sequences available in NCBI, we identified a conserved site on the exon 6 near domain V (Supplementary Fig. S1) and designed primers (F14, R12) targeted toward the conserved site, according to a previously published protocol ${ }^{31}$.

A real-time PCR assay was performed using PowerUp SYBR Green Master Mix and a StepOne instrument (Life Technologies). A 10- $\mu \mathrm{L}$ mix for each PCR run was prepared as follows: $3 \mu \mathrm{L}$ water, $0.5 \mu \mathrm{L}$ of each primer $(0.5 \mu \mathrm{M}), 1 \mu \mathrm{L}$ DNA template, and $5 \mu \mathrm{L}$ Fast SYBR Green Master mix. The reactions were performed using a Fast cycling mode: (1) $50^{\circ} \mathrm{C}, 120 \mathrm{~s}$; (2) $95^{\circ} \mathrm{C}, 120 \mathrm{~s}$; (3) $95^{\circ} \mathrm{C}, 3 \mathrm{~s}$; (4) $60^{\circ} \mathrm{C}, 30 \mathrm{~s}$; (5) Back to (3) 39 times, (6) $95^{\circ} \mathrm{C}, 15 \mathrm{~s}$; (7) $\left.60^{\circ} \mathrm{C}, 60 \mathrm{~s} ;(8) 95^{\circ} \mathrm{C}, 15 \mathrm{~s}\right)$. Average Ct values of two or three repetitions were obtained and used for analyses.

Standard curve generation with Showa strain. We prepared DNA templates for the standard curve of the real-time PCR assay using Showa strain (race B). The Showa strain was originally isolated in a greenhouse at the University of California, Berkeley ${ }^{32}$ and was distributed to our laboratory. We cultivated the Showa strain in a 1-L reactor with AF- 6 medium at $27^{\circ} \mathrm{C}$, with a photosynthetic photon flux density (PPFD) of $100 \mu \mathrm{mol} \cdot \mathrm{s}^{-1} \cdot \mathrm{m}^{-2}$ (14h per day) and $3 \% \mathrm{CO}_{2}$-bubbling. We diluted an aliquot of the Showa culture to make a 50 -mL sample containing $10^{6}$ Showa colonies. The sample was diluted sequentially 10 times with distilled water to make two series of 50-mL samples from $10^{5}$ to $10^{2}$ colonies. The $50-\mathrm{mL}$ samples were filtered individually with a $10-\mu \mathrm{m}$ membrane filters (JCWP04700, Merck), and the filters were frozen by liquid nitrogen and disrupted using a multi-bead shocker instrument (Yasui Kikai, Japan) at $3000 \mathrm{rpm}$ for $30 \mathrm{sec}$. DNA was extracted from the disrupted filter using a NucleoSpin Plant II (Macherey-Nagel, Germany) according to the manufacturer's protocol, and a 100- $\mu \mathrm{L}$ DNA solution was obtained from each sample. Real-time PCR assay was performed as described above using $1 \mu \mathrm{L}$ of the DNA solution as a template. The $\mathrm{Ct}$ values were plotted against $\log _{10}$-transformed colony densities per $\mu \mathrm{L}$ of DNA solution to make a standard curve. We also generated a standard reference curve using the target sequence cloned into a plasmid. The target sequence amplified from the DNA of Showa strain was cloned into pMD20 plasmid vector (TaKaRa, Japan), and the plasmids were extracted using NucleoSpin Plasmid EasyPure (Macherey-Nagel, Germany), following the manufacturer's protocols. The DNA concentrations of the plasmid sample were determined using a fluorometer (Qubit 2.0, Life Technologies). Average cell number per colony was estimated by counting cells of Showa colonies $(n=21)$ flattened by cover glass (Fig. 1c).

Amplification specificity in a natural environment. To test the PCR amplification specificity in a natural environment, we prepared a series of standard samples diluted in pond water. A 1-L sample of natural pond water was taken from a pond around Osaka castle, Osaka city, Japan in August 2017 using a plankton net with a $100-\mu \mathrm{m}$ mesh. Microscopic observations confirmed the presence of several microalgal species, including $B$. braunii, in the pond. Pond water was used to dilute an aliquot of Showa culture to prepare a 50-mL sample with $10^{6}$ Showa colonies (Supplementary Fig. S2). The sample was diluted 10X sequentially with pond water to make samples containing $10^{5}$ to $10^{2}$ Showa colonies (Series $\mathrm{P}$ ). For comparison, sample preparation was repeated using distilled water instead of pond water (Series W). The samples were filtered with membrane filters and DNA was extracted from the filters as described above. Real-time PCR assays were performed using the extracted DNAs as templates and standard curve relationships between $\mathrm{Ct}$ and colony density were compared between the two series.

Isolation of wild strains. Seventy wild B. braunii strains were isolated from tropical to temperate freshwater environments (Fig. 7). Microalgae in surface water were collected using a plankton net with a 100- $\mu \mathrm{m}$ mesh. A single colony of $B$. braunii was isolated by micropipette, transferred to a glass tube containing AF- 6 medium, and incubated at $25^{\circ} \mathrm{C}$ with a 12 -h light/12-h dark cycle with fluorescence lamps with a PPFD of $100 \mu \mathrm{mol} \mathrm{m}^{-2} \mathrm{~s}^{-1}$. After one month, colonies were transferred to $30-\mathrm{mL}$ culture bottles and incubated for an additional two months. Colonies were then collected with a $10-\mu \mathrm{m}$ filter membrane, and DNA was extracted from the filter. DNA concentration was determined by using a fluorometer (Qubit 2.0, Life Technologies) and was diluted to $1 \mathrm{ng} \mu \mathrm{L}^{-1}$.

$18 \mathrm{~S}$ ribosomal sequencing and molecular phylogeny. $18 \mathrm{~S}$ ribosomal RNA sequences were determined for the 70 isolated wild strains to estimate phylogenetic relationships with previously described strains ${ }^{23}$ and classify them into different chemical races. Either specific primers (63 F \& 1818R $)^{23}$ or universal primers (EukF1 \& EukR1) ${ }^{33}$ were used to amplify $18 \mathrm{~S}$ ribosomal RNA sequences (Supplementary Table S1) by EmeraldAmp PCR Mater Mix (TaKaRa Bio, Japan) including $0.2 \mu \mathrm{M}$ of primers and 1 ng of DNA template with the following thermal cycler program: $2 \mathrm{~min}$ at $95^{\circ} \mathrm{C} ; 34$ cycles of $95^{\circ} \mathrm{C} / 30 \mathrm{~s}, 55^{\circ} \mathrm{C} / 30 \mathrm{~s}, 72^{\circ} \mathrm{C} / 100 \mathrm{~s}$; and $5 \mathrm{~min}$ at $72^{\circ} \mathrm{C}$. The PCR products were directly sequenced. These sequences were aligned using ClustalW with additional reference sequences obtained from NCBI. Neighbour-joining (NJ) analysis with the Tamura-Nei model of genetic distance was performed using the sequence of Choricystis sp., the closest species to Botryococcus among the members of Trebouxiophyceae ${ }^{23}$, as an outgroup. Bootstrap values of 1000 replicates were obtained using Geneious R11. 

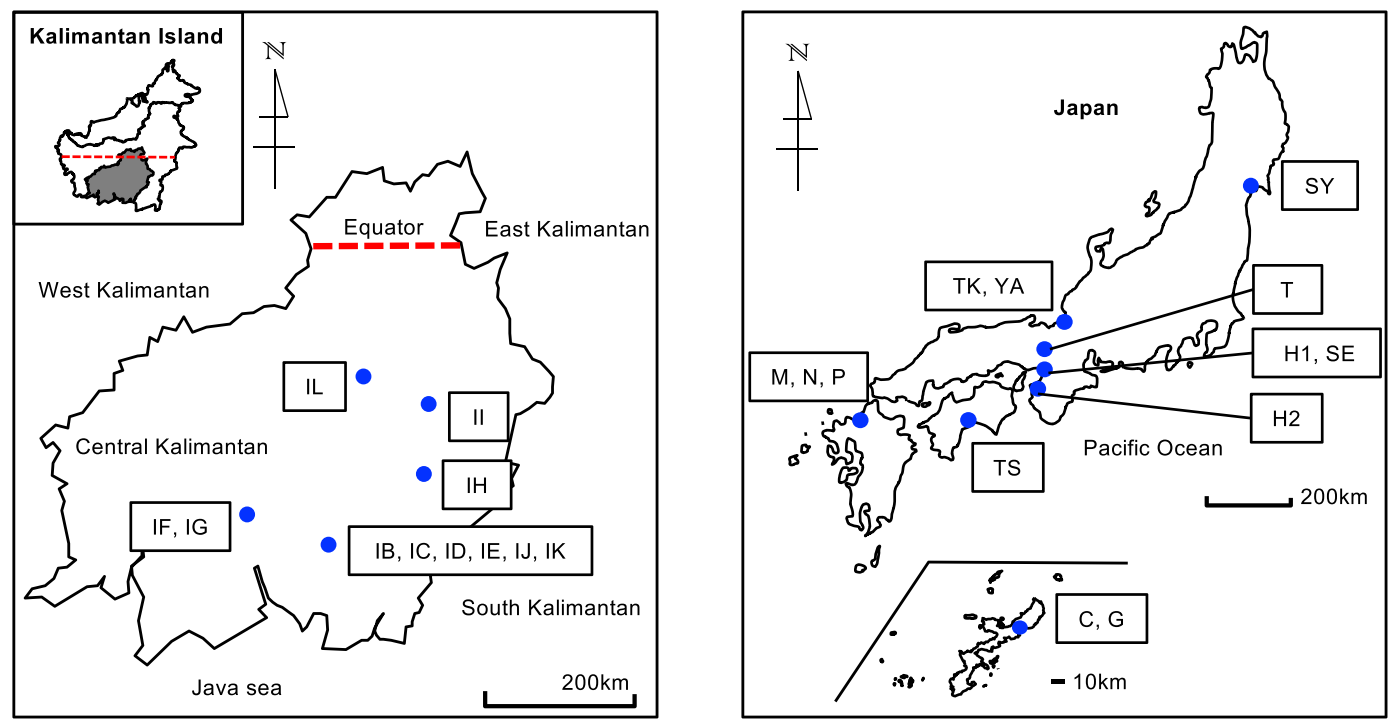

Figure 7. Map of the sampling locations of wild Botryococcus braunii at Central Kalimantan, Indonesia, and Japan. Palangka Raya (Pond IB, IC, ID, IE, IJ, IK); Pundu (IF, IG); Buntok (IH); Muara Teweh (II); Sungei Hanyo (IL); Okinawa (C, G); Fukuoka (M, N, P); Kochi (TS); Fukui (TK, YA); Wakayama (H2); Osaka (H1, SE); Kyoto (T); Miyagi (SY). A total of 70 wild strains were isolated from the 24 ponds distributed from tropics (Indonesia), subtropics (Okinawa), warm temperate (Fukuoka, Kochi, Fukui TK, Wakayama, Osaka, Kyoto), and cool temperate regions (Miyagi, Fukui YA).

Compatibility of SSL3-gene primers with wild strains. To assess the wide applicability of our real-time PCR method for detecting and quantifying wild B. braunii in natural environments, we tested the efficiency of our PCR amplification for 70 wild strains based on the theory of relative quantification with an internal control gene ${ }^{34}$. First, real-time PCR assays were performed using the SSL-3 gene primers and DNA templates of wild strains, and $\mathrm{Ct}$ values $\left(\mathrm{Ct}^{\mathrm{SSL3}}\right)$ were obtained. Next, as an internal control, we designed primers targeted toward a conserved region of $18 \mathrm{~S}$ ribosomal RNA sequences of the 70 wild strains: Bot18S_qF1 and Bot18S_qR1 (Supplementary Table S1) and real-time PCR assays were performed using the 18S primers and the same DNA templates of wild strains to obtain $\mathrm{Ct}$ values $\left(\mathrm{Ct}^{18 \mathrm{~S}}\right)$. The differences of the $\mathrm{Ct}$ values, $\Delta \mathrm{Ct}\left(=\mathrm{Ct}^{\mathrm{SLL3}}-\mathrm{Ct}^{18 \mathrm{~S}}\right)$ were calculated for each strain. The $\Delta \mathrm{Ct}$ is expected to increase if the SSL-3 primers did not match the template DNA. The $\Delta(\Delta \mathrm{Ct})$ value was calculated as $\Delta(\Delta \mathrm{Ct})=\Delta \mathrm{Ct}^{\text {wild strain }}-\Delta \mathrm{Ct}$ showa. The $\Delta(\Delta \mathrm{Ct})$ is expected to be zero when PCR amplification efficiencies of target and internal control genes are identical to those of the Showa strain, and would increase as the PCR amplification efficiency of the target sequence decreases. The relative level of PCR amplification efficiency was estimated as $2^{-\Delta(\Delta \mathrm{Ct})}$.

Field testing in a natural habitat. In pond IE, Palangka Raya, Kalimantan Island, Indonesia, we performed field testing of the real-time PCR assay. Pond IE was created more than 20 years ago at an ex-mining site and has been utilized as a recreational pond for boating and fishing. The pond naturally holds water throughout the year. We first found a natural B. braunii population in the pond in August 2015. In September 2017, 10-L surface water samples were taken from the centre of the pond every three hours to estimate colony density and its diurnal changes in the pond. The sample was filtered by a phytoplankton net with a $100 \mu \mathrm{m}$ mesh and was concentrated to $100 \mathrm{~mL}$. The $100-\mathrm{mL}$ sample was filtered under reduced pressure with a dual Kimwipe paper, then the paper was freeze-dried, a quarter of which was used for DNA extraction by the previously described method. A $1-\mu \mathrm{L}$ DNA solution was used for the real-time PCR assay to estimate the number of $B$. braunii colonies $\left(\mathrm{L}^{-1}\right)$ in the surface water. Water temperature, $\mathrm{pH}$, and electrical conductivity (EC) were also determined at sampling time. Once per day (at 5 p.m.), we also obtained additional 10-L samples from depths of 50,100, and $150 \mathrm{~cm}$ to estimate vertical changes in colony densities. The approximate water depth at the sampling point was $150-200 \mathrm{~cm}$. The following year, in October 2018, 5-L surface water samples were taken from three points along the shore of the pond to estimate the distribution of $B$. braunii in different-sized particles in the water. The sampled water was filtered with $20-\mu \mathrm{m}, 10-\mu \mathrm{m}$, and $1-\mu \mathrm{m}$ membrane filters sequentially, then DNA was extracted from the filters as described above. We also manually sampled bottom sediments in the centre of the pond, and DNA was extracted from 0.5-g soil samples using ISOIL for bead beating (NIPPON GENE, Japan) according to the manufacturer's protocol. Six replicates were used for the soil DNA extraction. Colony density $\left(\mathrm{L}^{-1}\right.$ water or $\mathrm{g}^{-1}$ soil) was calculated from the Ct value and the volume of filtered water or the weight of soil.

\section{Data availability}

$18 \mathrm{~S}$ ribosomal RNA sequences of the 70 wild Botryococcus braunii strains are available from DDBJ (Accession no. LC468958-LC469027). 
Received: 28 March 2019; Accepted: 4 November 2019;

Published online: 18 November 2019

\section{References}

1. Chisti, Y. Biodiesel from microalgae. Biotechnol. Adv. 25, 294-306 (2007).

2. Wijffels, R. H. \& Barbosa, M. J. An outlook on microalgal biofuels. Science 329, 796-799 (2010).

3. Moody, J. W., McGinty, C. M. \& Quinn, J. C. Global evaluation of biofuel potential from microalgae. PNAS 111, 8691-8696 (2014).

4. Yoshida, M., Tanabe, Y., Yonezawa, N. \& Watanabe, M. M. Energy innovation potential of oleaginous microalgae. Biofuels. 3 , 761-781 (2012).

5. Lee, S. Y., Kim, H. M. \& Cheon, S. Metabolic engineering for the production of hydrocarbon fuels. Curr. Opin. Biotechnol. 33, 15-22 (2015).

6. Suzuki, R. et al. Transformation of Lipid Bodies Related to Hydrocarbon Accumulation in a Green Alga, Botryococcus braunii (Race B). PLoS One 8, e81626, https://doi.org/10.1371/journal.pone.0081626 (2013).

7. Hillen, L. W., Pollard, G., Wake, L. V. \& White, N. Hydrocracking of the oils of Botryococcus braunii to transport fuels. Biotechnol. Bioeng. 24, 193-205 (1982).

8. Murata, K., Liu, Y., Watanabe, M. M., Inaba, M. \& Takahara, I. Hydrocracking of algae oil into aviation fuel-range hydrocarbons using a Pt-Re catalyst. Energ. Fuels 28, 6999-7006 (2014).

9. Glikson, M., Lindsay, K. \& Saxby, J. Botryococcus-A planktonic green alga, the source of petroleum through the ages: transmission electron microscopical studies of oil shales and petroleum source rocks. Org. Geochem. 14, 595-608 (1989).

10. Moldowan, J. M. \& Seifert, W. K. First discovery of botryococcane in petroleum. J. Chem. Soc. Chem. Commun. 19, 912-914 (1980).

11. Mckirdy, D. M., Cox, R. E., Volkman, J. K. \& Howell, V. J. Botryococcane in a new class of Australian non-marine crude oils. Nature 320, 57-59 (1986).

12. Banerjee, A., Sharma, R., Chisti, Y. \& Banerjee, U. C. Botryococcus braunii: a renewable source of hydrocarbons and other chemicals. Crit. Rev. Biotechnol. 22, 245-279 (2002).

13. Metzger, P. \& Largeau, C. Botryococcus braunii: a rich source for hydrocarbons and related ether lipids. Appl. Microbiol. Biotechnol. 66, 486-496 (2005).

14. Yoshimura, T., Okada, S. \& Honda, M. Culture of hydrocarbon producing microalga Botryococcus braunii strain Showa: Optimal $\mathrm{CO}_{2}$, salinity, temperature, and irradiance conditions. Biores. Technol. 133, 232-239 (2013).

15. Wake, L. V. \& Hillen, L. W. Study of a bloom of the oil rich alga Botryococcus braunii in the Darwin River reservoir. Biotech. Bioeng. 22, 1637-1565 (1980).

16. Aaronson, S. et al. Some observations on the green planktonic alga, Botryococcus braunii and its bloom form. J. Plankton Res. 5, 693-700 (1983).

17. Papa, R. D. et al. Blooms of the colonial green algae, Botryococcus braunii Kützing, in Paoay lake, Luzon island, Philippines. Philipp. J. Syst. Biol. 2, 21-26 (2008).

18. Demura, M. et al. Succession of genetic diversity of Botryococcus braunii (Trebouxiophyceae) in two Japanese reservoirs. Procedia Environ. Sci. 15, 3-11 (2012).

19. Janse van Vuuren, S. \& Levanets, A. First record of Botryococcus braunii Kützing from Namibia. Bothalia 49, a2382, https://doi. org/10.4102/abc.v49i1.2382 (2019).

20. Tanabe, Y. et al. A novel alphaproteobacterial ectosymbiont promotes the growth of the hydrocarbon-rich green alga Botryococcus braunii. Sci. Rep. 5, 10467, https://doi.org/10.1038/srep10467 (2015).

21. Niehaus, T. D. et al. Identification of unique mechanisms for triterpene biosynthesis in Botryococcus braunii. PNAS 108, 12260-12265 (2011).

22. Thapa, H. R. et al. A squalene synthase-like enzyme initiates production of tetraterpenoid hydrocarbons in Botryococcus braunii Race L. Nat. Comm. 7, 11198, https://doi.org/10.1038/ncomms11198 (2016).

23. Kawachi, M., Tanoi, T., Demura, M., Kaya, K. \& Watanabe, M. M. Relationship between hydrocarbons and molecular phylogeny of Botryococcus braunii. Algal Res. 1, 114-119 (2012).

24. Maxwell, J. R., Douglas, A. G., Eglinton, G. \& McCormick, A. The Botryococcenes-hydrocarbons of novel structure from the alga Botryococcus braunii, Kützing. Phytochemistry 7, 2157-2171 (1968).

25. He, D., Simoneit, B. R. T. \& Jaffé, R. Environmental factors controlling the distributions of Botryococcus braunii (A, B and L) biomarkers in a subtropical freshwater wetland. Sci. Rep. 8, 8626, https://doi.org/10.1038/s41598-018-26900-9 (2018).

26. Kim, B. H. et al. Simple, rapid and cost-effective method for high quality nucleic acids extraction from different strains of Botryococcus braunii. PLoS One 7, e37770, https://doi.org/10.1371/journal.pone.0037770 (2012).

27. Browne, D. R. et al. Draft nuclear genome sequence of the liquid hydrocarbon-accumulating green microalga Botryococcus braunii race B (Showa). Genome Announc. 5, e00215-17, https://doi.org/10.1128/genomeA.00215-17 (2017).

28. Weiss, T. L. et al. Phylogenetic placement, genome size, and GC content of the liquid-hydrocarbon-producing green microalga Botryococcus braunii strain Berkeley (Showa) (Chlorophyta). J. Phycol. 46, 534-540 (2010).

29. Ioki, M. et al. Modes of hydrocarbon oil biosynthesis revealed by comparative gene expression analysis for race A and race B strains of Botryococcus braunii. Biores. Technol. 109, 271-276 (2012).

30. Tanoi, T., Kawachi, M. \& Watanabe, M. M. Iron and glucose effects on the morphology of Botryococcus braunii with assumption on the colony formation variability. J. Appl. Phycol. 26, 1-8 (2014).

31. Thornton, B. \& Basu, C. Real-time PCR (qPCR) primer design using free online software. Biochem. Mol. Biol. Educ. 39, 145-154 (2011).

32. Nonomura, M. Botryococcus braunii var. showa (Chlorophyceae) from Berkeley, California, United States of America. Jpn. J. Phycol. 36, 285-291 (1988).

33. Moon-van der Staay, S. Y. et al. Abundance and diversity of prymnesiophytes in the picoplankton community from the equatorial Pacific Ocean inferred from 18S rDNA sequences. Limnol. Oceanogr. 45, 98-109 (2000).

34. Pfaffl, M. W. Quantification strategies in real-time PCR. [Bustin, S. A. (ed.)] A-Z of Quantitative PCR. 89-113. (La Jolla: International University Line, 2004).

\section{Acknowledgements}

This study was partially supported by a fund from JSPS KAKENHI (No. 26660179). We appreciate the members of Laboratory of Bio-environmental Sciences of OIT, Dontes R Siburian Zakiah, Noorkumala Sari Nisa, Andri Cornelius of UPR, and Widha Prahastika of UNMUL for their helpful support with the fieldwork.

\section{Author contributions}

K.K. conceived the research and drafted the manuscript. K.H. and T.H. performed experiments and drafted the manuscript. K.K., K.H., T.H., A., R.A.N., H.S., N.T., G.S. and Y.K. conducted fieldwork and sampling. S.O. provided the strain Showa and guided microalgal cultivation. All authors contributed to the final manuscript editing. 


\section{Competing interests}

The authors declare no competing interests.

\section{Additional information}

Supplementary information is available for this paper at https://doi.org/10.1038/s41598-019-53619-y.

Correspondence and requests for materials should be addressed to K.K.

Reprints and permissions information is available at www.nature.com/reprints.

Publisher's note Springer Nature remains neutral with regard to jurisdictional claims in published maps and institutional affiliations.

(c) (i) Open Access This article is licensed under a Creative Commons Attribution 4.0 International License, which permits use, sharing, adaptation, distribution and reproduction in any medium or format, as long as you give appropriate credit to the original author(s) and the source, provide a link to the Creative Commons license, and indicate if changes were made. The images or other third party material in this article are included in the article's Creative Commons license, unless indicated otherwise in a credit line to the material. If material is not included in the article's Creative Commons license and your intended use is not permitted by statutory regulation or exceeds the permitted use, you will need to obtain permission directly from the copyright holder. To view a copy of this license, visit http://creativecommons.org/licenses/by/4.0/.

(C) The Author(s) 2019 